\title{
ORGANIC FOOD MARKET IN JAVA AND BALI: CONSUMER PROFILE AND MARKETING CHANNEL ANALYSIS
}

\author{
Pasar Pangan Organik di Jawa dan Bali: \\ Profil Konsumen dan Analisis Saluran Pemasaran
}

\author{
Mukhamad Najib, Ujang Sumarwan, Stevia Septiani \\ Institut Pertanian Bogor, Kampus IPB, Jl. Raya Dramaga, Babakan, Kec. Dramaga, \\ Bogor, 16680, Jawa Barat, Indonesia \\ Email: najib@apps.ipb.ac.id
}

Naskah diterima: 28/07/2020; Naskah direvisi: 23/11/2020; Disetujui diterbitkan: 01/12/2020;

Dipublikasikan online: 18/12/2020

\begin{abstract}
Abstrak
Tren keamanan pangan menjadi isu sensitif dalam industri pangan saat ini. Pertanian organik dapat menjadi alternatif solusi karena memiliki keseimbangan lingkungan, kesehatan, dan kebermanfaatan bagi petani lokal. Namun, tingginya harga produk serta skala produksi yang masih rendah menjadi faktor yang membatasi pertumbuhan pasar pangan organik di dalam negeri. Penelitian ini bertujuan menganalisis perilaku konsumen pangan organik, menganalisis saluran pemasaran dan memformulasikan alternatif saluran pemasaran pangan organik dalam negeri. Pengambilan sampel dilakukan secara purposive dimana kriteria responden adalah mereka yang mengetahui pangan organik dan berdomisili di lima kota besar pulau Jawa dan Bali. Survei saluran pemasaran dilakukan di Jakarta dan Jawa Barat dengan mewawancarai aktor-aktor di setiap rantai nilai. Hasil penelitian menunjukkan peluang pasar pangan organik cukup besar, karena umumnya responden telah menyadari bahwa pangan organik baik untuk kesehatan. Konsumen pangan organik saat ini termasuk kelompok middle class segment berusia 20-50 tahun, pekerja kantoran dan berpenghasilan di atas Rp 9 juta. Bagi konsumen, label sertifikasi pangan organik lebih penting dari merek. Saluran pemasaran organik sangat bervariasi. Pada pasar B2C pemanfaatan digital marketing dapat meminimalisir risiko finansial petani organik. Sementara pasar B2B dapat dioptimalkan melalui kerja【sama perhotelan, restoran, kafe, rumah sakit, dan industri pengolahan makanan sehat, serta didukung kebijakan pemerintah yang selaras.
\end{abstract}

Kata Kunci: Pangan Organik, Perilaku Konsumen, Saluran Pemasaran, Negara Berkembang

\section{Abstract}

The trend of food safety is a sensitive issue in the food industry today. Organic agriculture can be an alternative solution because it has a right balance in terms of the environment, health and benefits for local farmers. However, high prices for organic products and low production scale limit the growth of the domestic organic food market. This research aims to analyze organic food's consumer behavior, analyze the existing marketing channels and formulate alternative marketing channels for the domestic organic food supply chain. Sampling was carried out by purposive sampling method in which the criteria for respondents were those who know about organic food and live in five big cities in Java and Bali. The marketing channel survey was conducted in Jakarta and West Java by interviewing each actor in the value chain. The results showed that organic food's market opportunity was quite large, because the respondents were generally aware that organic food was good for health. Organic food consumers are currently included in the middle-class segment, aged 20-50 years, office workers, and income more than IDR 9 million a month. For consumers, certification labels are more important than brands in organic food. On the one hand, organic marketing channels still vary widely. In the B2C market, the use of digital marketing can minimize the financial risks of organic farmers. On the other hand, the B2B market can be optimized through 
cooperation in hotels, restaurants, cafes, hospitals, and the healthy food processing industry, supported by government policies.

Keywords: Organic Food, Consumer Behavior, Marketing Channels, Developing Countries JEL Classifications: D11, F10, F18,

\section{INTRODUCTION}

The Indonesian government has long been concerned with organic farming. Organic farming is expected to support national food security since it can provide safe food products for the community. Moreover, organic farming can also encourage increased competitiveness of local farmers (Septiani, Najib \& Sumarwan, 2019). In 2010, the Indonesian republic's agriculture ministry launched the 'go organic' program to support organic farming practices. Then, the Go Organic program was strengthened by developing 1000 organic farming villages program in 2016 . The prospect of Indonesia becoming an organic foodproducing country is very prospective. In the Asian region, the country ranks fourth in those with the largest organic farming area, with a land area of 208 042 ha and ownership of producers of 17948 (FiBL, 2019). Data from the Indonesia Organic Alliance shows that in 2018 the domestic market demand for organic food has experienced positive growth, especially due to the development of online sales carried out by several organic food distributors. Sales growth of packaged organic food in Indonesia in 2017-2022 is forecast to reach $8.4 \%$ (Global Organic Trade Guide, 2018).

Although organic food has good prospects in the Indonesian market, the actual growth is still relatively low compared to their potential. The market share of organic food is still very small compared to the conventional product. The high price of organic products and the low production scale limit the domestic organic food market's growth. Strategic efforts to increase the growth of Indonesia's organic food market and maintain current market growth are needed. However, the organic farming system is still considered riskier by Indonesian farmers, in which at the initial stage the costs required are greater while in terms of productivity levels are lower than conventional farming (Hubeis et al., 2013). Some farmers are also hesitant in adopting an organic farming system because they consider the process too complicated, 
especially in the certification process, and feel the production costs are too high while the farmers do not have enough capital (Harris et al., 2000; Soltani et al., 2014).

The higher production costs affect the price of organic food at the consumer level. Organic food becomes more expensive than conventional food (Radman, 2005). In general, consumers who are not aware of organic food's benefits often do not want to buy products at high prices (Muzayanah et al., 2015; Wang et al., 2019). Moreover, according to Rodríguez-Bermúdez et al. (2020), most studies have found that price remains to be a barrier to the widespread consumption of organic products. As a result, farmers are worried about implementing organic farming systems since they are worried about limited markets while farmers themselves do not have enough ability to properly market their products (Groff et al., 1993).

Considering the above obstacles that the organic food market faces, organic farming will continue to grow if farmers have enough incentive to implement organic farming systems, especially market incentives such as the opportunity to get a premium price and benefit, higher potential market size, and many more. In this context, an overview of Indonesia's organic food market is essential to be analyzed to convince farmers and other stakeholders about market opportunities and its prospect. The description of market characteristics can also be useful information for farmers and organic farming entrepreneurs to formulate appropriate strategies to develop their markets. Research on the organic food market characteristics has been widely carried out in developed countries (Kaygisiz et al., 2019; VegaZamora et al., 2020; Torres-Ruiz et al., 2018). Of course, organic foods' market characteristics have differences between developed and developing countries, especially in terms of value, lifestyle, and purchasing patterns. Therefore, market characteristics, including consumer behavior, must be directed precisely for different regions and countries as perceptions and attitudes vary across the world (Rodríguez-Bermúdez et al., 2020).

This research aims to analyze organic food's consumer behavior, analyze the existing marketing channels in the organic food supply chain, and formulate alternative marketing 
channels for the domestic organic food supply chain. This research aims to provide a complete picture of the characteristics of the organic food market in developing countries by analyzing comprehensively from consumers and marketing channels perspectives.

\section{METHODS}

A survey has collected primary data into two groups: consumers and actors in marketing channels. Consumer surveys were conducted in the capital of five provinces located on Java and Bali islands, namely Jakarta, Bandung, Semarang, Surabaya, and Denpasar. So far, the five provincial capitals are the largest markets for organic foods in Indonesia (Global Organic Trade Guide, 2018).

Data at the consumer level was collected through in-depth interviews and self-administered samples of selected respondents from MaySeptember 2018. Due to the population data is not available, a sample of 550 respondents was obtained through the Lemeshow et al. (1997) approach. Sampling was carried out by purposive sampling method in which the criteria for respondents were those who know about organic food and live in 5 big cities in Java and Bali. The sample was collected in the modern market, such as supermarkets, hypermarkets, and specialty fruit and vegetable shops. In this case, the buyer who comes to those markets during the survey period can be a target respondent. The marketing channel survey was conducted in DKI Jakarta and West Java by interviewing each actor in the value chain.

The collected questionnaires were then cleaned, incomplete questionnaires were issued, so that the total questionnaires that could be continued in processing data consisted of 527 questionnaires. The primary data of the study were processed with descriptive analysis techniques to see the frequency distribution of consumer characteristics.

The Chi-square analysis was used in this study to assess whether an association exists between the two variables by comparing the observed pattern of responses in the cells to the pattern that would be expected if the variables were genuinely independent of each other. The Chi-Square statistic is most commonly used to evaluate Tests of Independence when using a crosstabulation analysis (Sotarra \& Bentler, 2010). The calculation of the Chi-Square statistic is relatively straightforward, as follow: 
$\chi^{2}=\sum \frac{\left(f_{0}-f_{e}\right)^{2}}{f_{e}}$

Where:

$f_{o}=$ the observed frequency (the observed counts in the cells)

$f_{e}=$ the expected frequency if No relationship existed between the variables

If the Asymp value. Sig. (2-sided)

Chi-Square count is smaller than $\alpha$; then there is a measured relationship between variables. The alpha used is 5 percent $(\alpha=0.05)$. After conducting a consumer survey and analysis, the next step is surveying marketing channel actors. The survey on actors involved in marketing channels was conducted in DKI Jakarta and West Java. Those provinces were chosen because of the large number of organic food producers in the region. Also, the proximity of production locations with marketing channels and consumers is considered in determining the sample.

\section{RESULTS AND DISCUSSION}

This section presents the findings of the survey. It begins with an explanation of the general characteristics of the respondents. The demographic profile of organic food consumers can be highlighted at Table 1. Organic food consumers in Indonesia are dominated by the female $(69.8 \%)$. In terms of age, $42.5 \%$ of the respondents were 20-29 years old. The majority of the respondents were bachelor's degrees making up 75\%. Additionally, most of them earned more than IDR 9 Million per month (29\%). In terms of respondents' profession, the largest proportion making $63 \%$ of the sample were those employed as office worker. Based on these data, it can be concluded that organic food's consumer profile is classified as a middle-class segment. This result supports the research conducted by Hughner et al. (2007) that organic food consumers are groups with good education and more women. 
Table 1. Profile of Organic Food Consumers

\begin{tabular}{llcc}
\hline Demographics & Criteria & $\begin{array}{c}\text { Frequency } \\
\text { (N= 527) }\end{array}$ & $\begin{array}{c}\text { Percentage } \\
\mathbf{( 1 0 0 \% )}\end{array}$ \\
\hline Gender & Male & 159 & 30.2 \\
Age & Female & 368 & 69.8 \\
& Less than 20 & 8 & 1.5 \\
& $20-29$ & 224 & 42.5 \\
Academic & $30-39$ & 122 & 23.1 \\
qualification & $40-50$ & 116 & 22 \\
& More than 50 & 57 & 10.9 \\
Monthly income & Under senior high school & 10 & 18 \\
& Senior high school & 62 & 11.8 \\
& Bachelor degree & 395 & 75 \\
& Master/doctoral degree & 60 & 11.4 \\
& Less than Rp 3 million & 137 & 26 \\
Job & Rp 3-5 million & 104 & 19.7 \\
& Rp 5-7 million & 85 & 16.1 \\
& Rp 7-9 million & 48 & 9.2 \\
Domicile & More than Rp 9 million & 153 & 29 \\
& Office worker & 332 & 63 \\
& Self-employ/entrepreneur & 105 & 20 \\
& Student & 90 & 17 \\
& Jakarta & 111 & 21 \\
& Bandung & 116 & 22 \\
& Semarang & 100 & 19 \\
& Surabaya & 100 & 19 \\
& Bali & 100 & 19 \\
\hline
\end{tabular}

Consumer Perception, Priority positive perception about the product Attribute, and Type of Organic Food will affect the attitudes and interests of Consumer perception about consumers towards the product. This organic food is essential to be identified study indicates that Indonesian as it influences consumers' attitudes and interests towards organic food. There have been many studies on the effect of perceptions on consumers' attitudes and interests (Basha et al., 2015; Iqbal, 2015; Oroian et al., 2017; Sultan et al., 2018) and generally consumers have a positive perception of organic food (Table 2), where organic food is considered healthier and fresher than conventional food. This positive perception will certainly also have a positive impact on consumer interest in consuming organic food.

produce the same conclusion where a 
Table 2. Consumer Perception on Organic Food

\begin{tabular}{llcc}
\hline No & Perception & $\begin{array}{c}\text { Frequency } \\
(\mathbf{N = 5 2 7 )}\end{array}$ & $\begin{array}{c}\text { Percentage } \\
(\%)\end{array}$ \\
\hline 1 & Better taste & 53 & 10 \\
2 & Fresher than other products & 126 & 24 \\
3 & Good for health & 190 & 36 \\
4 & Not contain pesticides and other & 58 & 11 \\
& chemicals & & \\
5 & More expensive & 53 & 10 \\
6 & Good for the environment & 21 & 4 \\
7 & Trendy/fashionable to consume organic & 26 & 5 \\
& food & & \\
\hline
\end{tabular}

Table 3. Priority Attribute Considered by Consumer

\begin{tabular}{llcc}
\hline No & Attribute & $\begin{array}{c}\text { Frequency } \\
(\mathrm{N}=527)\end{array}$ & $\begin{array}{c}\text { Percentage } \\
(\%)\end{array}$ \\
\hline 1 & Label & 57 & 10.8 \\
2 & Sensory aspect & 67 & 12.7 \\
3 & Chemical free & 98 & 18.6 \\
4 & Nutritious & 128 & 24.3 \\
5 & Price & 177 & 33.6 \\
\hline
\end{tabular}

Despite having a positive view of organic products as healthy and fresh, consumers' most important attribute is the price. Table 3 shows the priority attributes of organic foods considered by consumers when buying organic food is dominated by two things: the price and nutritional content in products. This consideration is different from consumers in developed countries such as America, Europe, and Australia, where essential attributes taken into consideration when buying organic food products are fresh and healthy aspects. (Pearson et al., 2010; Shepherd et al., 2005; Magnusson et al., 2003).
Consumers in developing countries are generally price-sensitive, including consumers in Indonesia. (Yee et al., 2011). So it is expected that Indonesian consumers use price as the primary consideration when buying organic products. This study indicates that most organic food products consumed by Indonesian consumers are vegetables, rice, and fruit (Table 4). Rice is the staple food of Indonesian people, and culturally the people of Indonesia consume rice with vegetables. So actually, the product is a daily need for Indonesian consumers. 


\section{Usage Characteristic}

The majority of respondents $(54.6 \%)$ in this study consumed organic food within less than a year (Table 5). While those who consume more than three years, only $14 \%$. The majority of respondents $(52 \%)$ consumption pattern is occasionally, while those who regularly consume are relatively high, 48 percent. Those who consume regularly, most of them consume organic food once a week $(30 \%)$, while the highest are those who consume organic food whenever they like (36.4\%).

Table 4. Type of Organic Food Product

\begin{tabular}{llcc}
\hline No & Type of Product & Frequency $(\mathbf{N}=\mathbf{5 2 7})$ & Percentage $(\%)$ \\
\hline 1 & Vegetable & 316 & 60 \\
2 & Rice & 265 & 50.3 \\
3 & Fruit & 158 & 30 \\
4 & Egg & 54 & 10.2 \\
5 & Spice & 54 & 10.2 \\
6 & Chicken & 37 & 7 \\
7 & Meat & 26 & 5 \\
\hline
\end{tabular}

\section{Table 5. Usage Characteristics}

\begin{tabular}{llcc}
\hline Usage & Characteristic & $\begin{array}{c}\text { Frequency } \\
(\mathbf{N = 5 2 7})\end{array}$ & $\begin{array}{c}\text { Percentage } \\
(\%)\end{array}$ \\
\hline How long have you used organic food & < 1 year & 288 & 54.6 \\
& 1-3 Years & 161 & 30.6 \\
& $>$ 3 years & 78 & 14.8 \\
Pattern of consumption & Never & 0 & 0 \\
& Regular basis & 253 & 48 \\
& Occasionally & 274 & 52 \\
Frequency of consumption & & & \\
& Everyday & 69 & 13.1 \\
& Once a week & 158 & 30.0 \\
& Once a month & 108 & 20.5 \\
& Sometime & 192 & 36.4 \\
\hline
\end{tabular}

\section{The Role of Brands and Labels}

Percsi \& Fogarassy (2019) found that branding and product labeling are not crucial in the consumer thought to purchase organic products. However, several studies have shown that brands and labels influence consumer purchasing decisions (Drexler et al., 2017; Jassen \& Hamm, 2012; Larceneux et al., 2012; Muhammad et al., 2016). Many studies supported that the brand and label are essential factors 
that must be considered by the producer.

In Indonesia's organic food market, labels become more important than the brand (Table 6). However, the effect of label depends on whether the consumers consider the additional information on the label facilitates their perception of the added value of the

organic food products. When the added value of the organic food products could be recognized by consumers, such as country of origin and certification source, organic producers and marketers may benefit from increasing their market power (Kim, Suwunnamek \& Toyoda, 2008).

Table 6. The Role of Brand and Label

\begin{tabular}{|c|c|c|c|c|}
\hline No & Brand and Label & Role & Frequency $(\mathrm{N}=527)$ & Percentage ( \% ) \\
\hline \multirow[t]{2}{*}{1} & Brand & Important & 182 & 34.5 \\
\hline & & Not important & 345 & 65.5 \\
\hline \multirow[t]{2}{*}{2} & Label / certification & Important & 386 & 73.2 \\
\hline & & Not important & 141 & 27.8 \\
\hline
\end{tabular}

The Place for Buying Organic Food

In Indonesia, organic food products are still considered a specialty good, which implies that products are not always available in many places. So far, modern retail has provided more organic food products compared to the traditional market. Generally, consumers in traditional markets also do not have enough organic product awareness (Table 7). The sale of organic food in traditional markets is considered less profitable since consumers treat it like ordinary food products where the prevailing price is normal.

\section{Table 7. The Most Preferable Place for Buying Organic Food}

\begin{tabular}{llcc}
\hline No & Place & Frequency (N=527) & Percentage ( \%) \\
\hline 1 & Hypermarket & 79 & 15 \\
2 & Supermarket & 190 & 36 \\
3 & Specialty fruit market & 216 & 41 \\
4 & Traditional market & 26 & 5 \\
5 & Others & 16 & 3 \\
\hline
\end{tabular}

The majority of consumers obtain organic food products from the specialty fruit market, followed by supermarkets and hypermarkets. The reason for 
selecting the intended market is that it provides more fresh organic products with good quality (reliable). Consumers also consider the variety of products and store distance in choosing where to buy organic food (Table 8). For consumers who are sensitive to prices, the perception of fair prices is very important in making purchasing decisions (Rodiger et al., 2016).

Table 8. Reason Choosing Type of Market

\begin{tabular}{llcc}
\hline No & Reason & Frequency $(\mathbf{N}=\mathbf{5 2 7})$ & Percentage (\%) \\
\hline 1 & Close to home & 107 & 20 \\
2 & Reliable & 116 & 22 \\
3 & Variety of products & 89 & 17 \\
4 & Fair price & 68 & 13 \\
5 & Good service & 30 & 6 \\
6 & Fresh products & 117 & 22 \\
\hline
\end{tabular}

Note: Every respondent may choose more than one

Demographic Aspects and Nowadays, organic products' potential

\section{Frequency of Consumption}

Table 9 shows that demographic aspects that significantly affect (in the level of 0.05) the frequency of consumption are monthly income and education level. Then, the factor which affects (at the level of 0.10 ) is profession. The data is supported by the interview results from organic producers' perspective. The producers confirm that Indonesia's consumer awareness of organic products has not been as popular as in Western countries, such as English, America, and Aussie. market covers the big cities in Indonesia, with the middle-up monthly income of customers \& well-educated customers, such as Java and Bali Island. These research findings are not really in line with previous studies. Research conducted by Sharma \& Singhvi (2018) found that when buying organic products, consumers in different countries are mainly influenced by gender, age, income, level of education, and children's presence in the household.

Table 9. Demographic aspect and frequency of consumption organic food

\begin{tabular}{llll}
\hline Category & Value & Df & P-Value \\
\hline Monthly income vs frequency of consumption & 12.370 & 5 & $0.002^{*}$ \\
Age vs frequency of consumption & 21.227 & 12 & 0.136 \\
Education vs frequency of consumption & 13.651 & 6 & $0.005^{*}$ \\
Gender vs frequency of consumption & 3.013 & 2 & 0.486 \\
Profession vs frequency of consumption & 5.404 & 4 & $0.067^{*}$ \\
\hline
\end{tabular}


Organic Food Marketing Channels

Unlike conventional products, organic products have a unique marketing approach. Traditional marketing is considered to be less relevant in promoting organic food. Muzayanah et al. (2015) stated that the inaccessibility constrains people's buying interest in organic products in terms of price and the lack of awareness of organic food benefits. Organic product marketing must pay attention to various aspects, such as consumer affordability, the right price, certification, and education.

The choice of marketing channels is important to provide decent income, especially for organic food producers. Each city had different marketing channels with its own marketing actors. Organic products were produced in five cities based on samples, namely vegetable, pineapple, banana, organic chicken, root and tuber, and rice. In general, organic consumers consisted of end-users, horeca (hotel, restaurant, and café), hospitals and international markets (through exporters). To be able to reach these consumers, there are several intermediary actors involved.

Each distribution channel from onfarm to the first distribution channel until the end-user, in general, used the calculation of the Cost of Good Manufactured (COGM) as a fair price determinant. However, there were several obstacles for farmers in accessing modern retail markets, which generally used the consignment approach and the goods return system. Additionally, farmers' marketing access constraints when distributing their products to hotels, restaurants, and cafes were in the payment system which was generally delayed payment. These constraints affected the sustainability of product procurement on the part of farmers and tended to harm farmers.

\section{Tabel 10. General Description of Organic Farming}

\begin{tabular}{|c|c|c|c|c|}
\hline City & Actor & Produced Product & $\begin{array}{l}\text { Potential } \\
\text { Market }\end{array}$ & $\begin{array}{l}\text { Sales } \\
\text { Coverage }\end{array}$ \\
\hline Bogor & $\begin{array}{l}\text { Traditional farmer, } \\
\text { middleman, } \\
\text { Cooperative, } \\
\text { Distributor farmer, } \\
\text { retail, } \\
\text { Individual agent }\end{array}$ & $\begin{array}{l}\text { Vegetable, } \\
\text { Pineapple, Banana, } \\
\text { Organic Chicken, } \\
\text { Root and Tuber }\end{array}$ & $\begin{array}{l}\text { Horeka } \\
\text { Hospital } \\
\text { End User }\end{array}$ & $\begin{array}{l}\text { Jakarta, } \\
\text { Bogor, } \\
\text { Depok, } \\
\text { Tangerang, } \\
\text { Bekasi }\end{array}$ \\
\hline Jakarta & $\begin{array}{l}\text { Distributor } \\
\text { foundation, organic } \\
\text { community, exporter }\end{array}$ & Rice & $\begin{array}{l}\text { End User } \\
\text { Exporter }\end{array}$ & International \\
\hline
\end{tabular}




\begin{tabular}{|c|c|c|c|c|}
\hline City & Actor & Produced Product & $\begin{array}{l}\text { Potential } \\
\text { Market }\end{array}$ & $\begin{array}{l}\text { Sales } \\
\text { Coverage }\end{array}$ \\
\hline Cianjur & $\begin{array}{l}\text { Association of } \\
\text { farmers groups, } \\
\text { cooperative, retail, } \\
\text { distributor farmer, } \\
\text { individual agent }\end{array}$ & $\begin{array}{l}\text { Japanese } \\
\text { Vegetable }\end{array}$ & $\begin{array}{l}\text { Horeca } \\
\text { End User }\end{array}$ & National \\
\hline Tasikmalaya & $\begin{array}{l}\text { Association of } \\
\text { farmers groups, } \\
\text { middleman, } \\
\text { exporter, retail }\end{array}$ & Rice & $\begin{array}{l}\text { Exporter } \\
\text { End user }\end{array}$ & International \\
\hline Bandung & $\begin{array}{l}\text { Modern farmer, } \\
\text { Modern retail }\end{array}$ & $\begin{array}{l}\text { Vegetable, } \\
\text { Seasoning } \\
\text { Vegetable }\end{array}$ & $\begin{array}{l}\text { End User } \\
\text { Horeka }\end{array}$ & Bandung \\
\hline
\end{tabular}

Jakarta Organic Product Marketing Channel

The marketing channel for organic products in Jakarta was divided into three marketing channels, as shown in Figure 1. The whole marketing channel involved four marketing actors, with the final objectives were the end-user and foreign markets. The marketing actors involved were farmers, distributors, retailers, and exporters. Jakarta's organic food marketing channel's uniqueness was that most of its products were distributed directly to consumers so that there were not too many marketing actors involved, and the marketing margin obtained by the farmer was increasing. One of the reasons was the geographical proximity to the producer. There are many people with middle to upper income in the capital city and are also educated. Direct sales to end-user also have reasonable implications for the producer, namely, the direct payment that is not deferred.

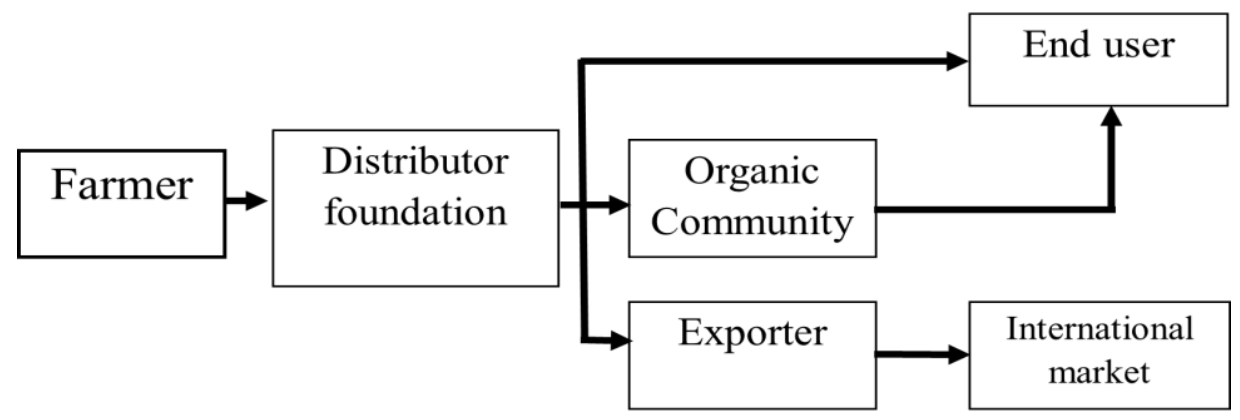

Figure 1. Jakarta Organic Product Marketing Channel 
Bogor Organic Product Marketing Channel

The marketing channel for organic products in Bogor was divided into six marketing channels, as in Figure 2. The whole marketing channel involved six marketing actors: farmer, cooperative, middleman, distributor farmer, retailer, and individual agent. The final objectives were the end-user and B2B, which are hospitals and restaurants.

In addition to modern farmers, in Bogor, organic food production was also done by the traditional farmer. Constraints from traditional farmers included difficulties in reaching market share and also the certification process. Therefore, cooperatives were formed to provide added value to farmers' products in branding, packaging, and channeling traditional farmers' products to end users/other marketing institutions with access to end-users. However, cooperatives had a maximum quantity of product purchases from farmers, so that not all farmers' products were absorbed into the cooperative. The excess products were sold to middlemen at a much cheaper price and the same as conventional products' price.

Modern producers in the city of Bogor already had access to their main sales through sales agents in Greater Jakarta. Modern producers in Bogor were well-known companies that had also succeeded in implementing sales strategies by minimizing farmers' losses, by implementing a system of selling out and not returning. The ability of modern farmers to access markets through the agency system made great demand from modern farmers. Therefore, modern Bogor producers also bought products from farmers/cooperatives and distributed them to the marketing network they had.

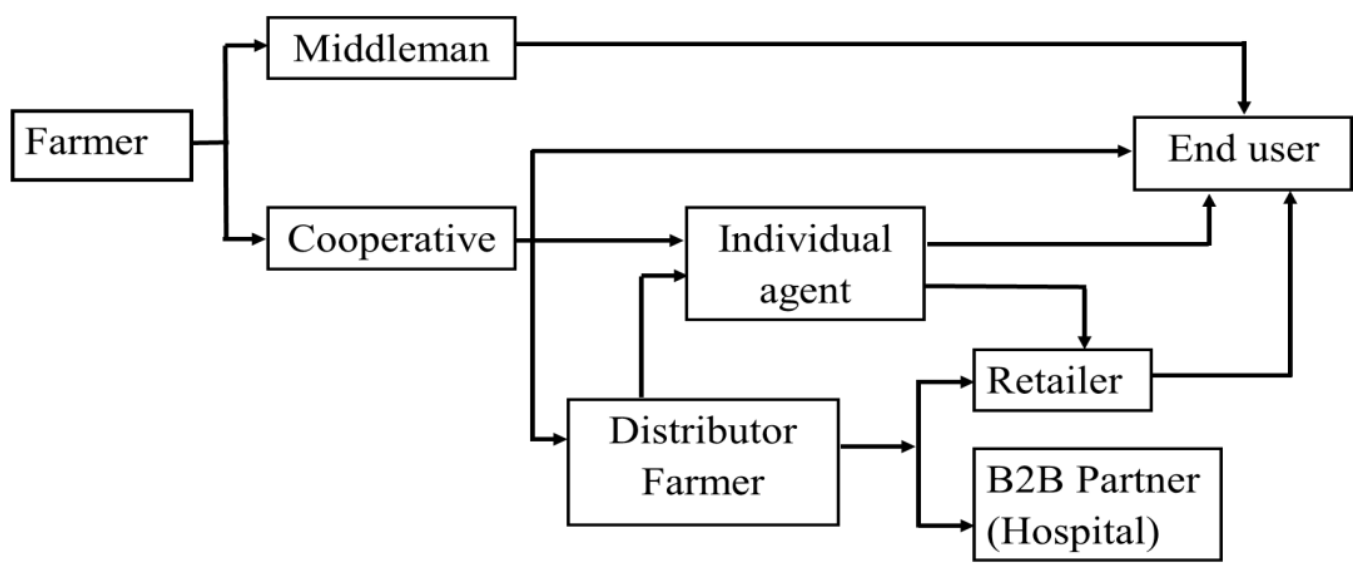

Figure 2. Bogor Organic Product Marketing Channel 
In the organic food value chain in the Bogor area, individual agents are the actors who get the largest proportion of the existing price transmission (see Table 11). Individual agents sell organic agricultural products, only organic pineapples with a one-time quantity of \pm
50 pineapples once a week. This agent sells pineapples to buyers directly or delivery orders via an Instagram platform called "Kebun_yursayur" and Whatsapp. The grades taken are levels $B$ and $C$ with the following price details:

\section{Table 11 Prices Transmission of Organic Pineapple}

\begin{tabular}{ccccccc}
\hline \multirow{2}{*}{ Grade } & $\begin{array}{c}\text { Prices at } \\
\text { farmers }\end{array}$ & $\begin{array}{c}\text { Price from the } \\
\text { cooperative }\end{array}$ & Agent & Proportion & End Customers & Proportion \\
\hline B & 3000 & 5000 & 12000 & & 15000 & $20 \%$ \\
C & 2500 & 4000 & 12000 & & 15000 & \\
\hline
\end{tabular}

\section{Bandung Organic Product Marketing Channel}

The marketing channel for the organic product in Bandung was divided into three marketing channels, as shown in Figure 3. The whole marketing channel involved two marketing actors with the final objectives: the end-user and $\mathrm{B} 2 \mathrm{~B}$, such as café and restaurant. The marketing actors involved were farmers and retailers. Similar to Jakarta,
Bandung also had the advantage of being close to consumers demographically. Producers of organic products can directly channel their products through retail in Bandung and to B2B (hotel, restaurant, and café) in the Bandung area. Marketing that was still in one city made it easy for producers to supply goods, handle goods to keep them fresh and reduce transportation costs.

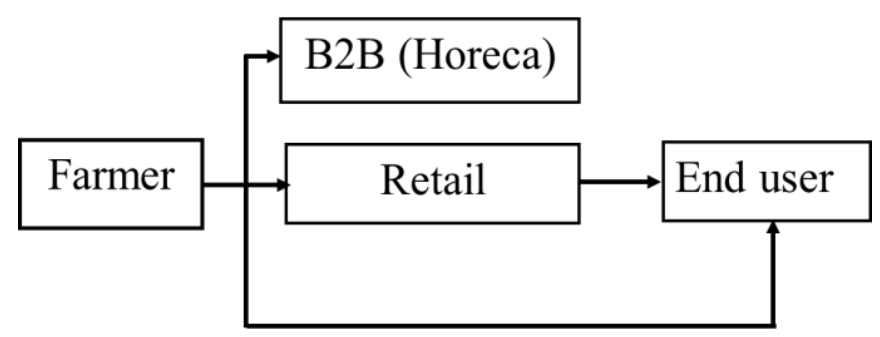

Figure 3. Bandung Organic Product Marketing Channel 
Cianjur Organic Product Marketing Channel

The marketing channel for organic products in Cianjur was divided into five types of marketing channels (Figure 4). The entire marketing channel involved eight marketing actors, with the final objectives were the end-user and B2B, for business consumers, were generally restaurants. Sales with the final objective to B2B (restaurants) made farmers there to have stable demand and not receive goods return, even in terms of payments the delayed payment system was used.

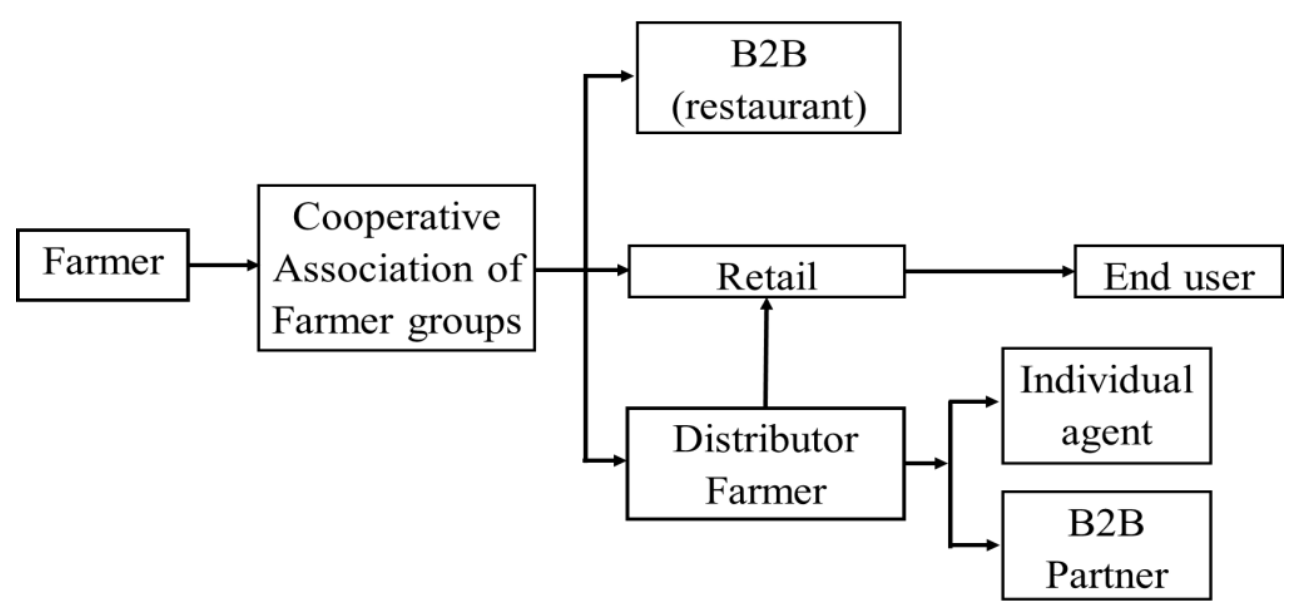

Figure 4. Cianjur Organic Product Marketing Channel

Tasikmalaya Organic Product (association of farmers groups) in Marketing Channel

The marketing channel for organic products in Tasikmalaya was divided into four marketing channels, as shown in Figure 5. The entire marketing channel involved six marketing actors with the end-user and the foreign market's final objectives. Gapoktan Tasikmalaya was partnering with exporters who sold the products abroad so that the most significant sales were overseas. Price determination from farmers to exporters, distributors, and retail is carried out by negotiation through meetings of internal parties and external parties. 


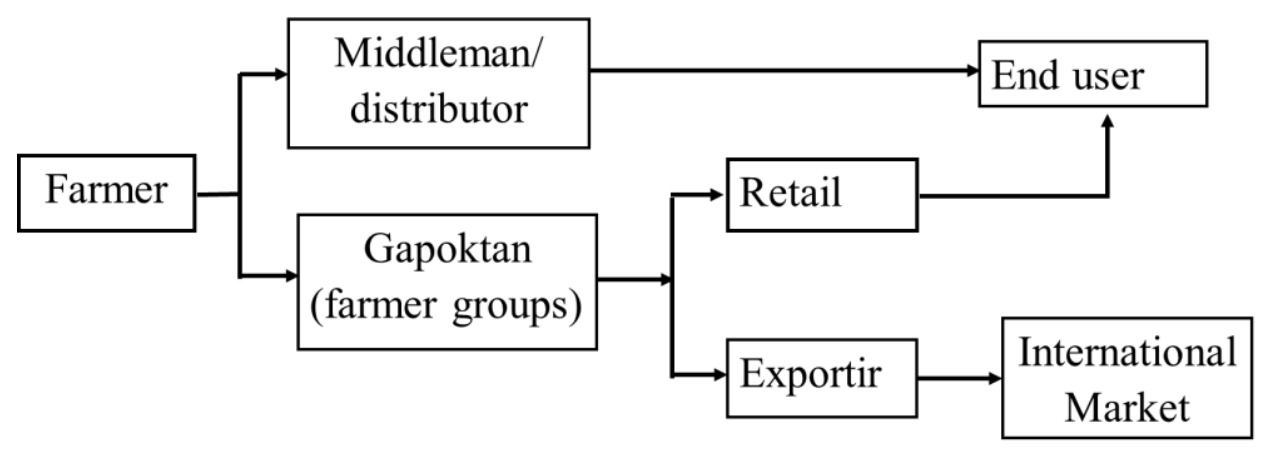

\section{Figure 5. Tasikmalaya Organic Product Marketing Channel}

Pricing from farmers to exporters, distributors, and retailers is carried out by negotiation through internal and external party meetings. The standard of quality for goods produced is the premium export quality for all commodities supplied. The price transmission in the organic food supply chain in Tasikmalaya is shown in Table 12.

Table 12. Price transmission of Simpatik's Gapoktan Rice

\begin{tabular}{|c|c|c|c|c|c|c|c|}
\hline $\begin{array}{l}\text { Type of } \\
\text { Commodity }\end{array}$ & $\begin{array}{l}\text { Prices of } \\
\text { Grain } \\
\text { (Rp/Kg) }\end{array}$ & $\begin{array}{c}\text { HPP } \\
\text { Farmers } \\
\text { (Rp/kg) }\end{array}$ & $\begin{array}{c}\text { Exporters } \\
\text { (Rp/kg) }\end{array}$ & $\begin{array}{l}\text { Retails } \\
\text { (Rp/Kg) }\end{array}$ & $\begin{array}{l}\text { End User } \\
\text { (Rp/kg) }\end{array}$ & $\begin{array}{l}\text { Payment } \\
\text { System }\end{array}$ & Portion \\
\hline White rice & Ganoktan & 13.000 & 16.500 & & $\pm 5-6$ Euro & End Selling & \multirow{3}{*}{$\begin{array}{l}75-100 \\
\text { ton }\end{array}$} \\
\hline Brown rice & offers & 14.000 & 17.000 & & $\pm 5-6$ Euro & End Selling & \\
\hline Black Rice & higher & 15.000 & 18.000 & & $\pm 5-6$ Euro & End Selling & \\
\hline White rice & prices to & 13.000 & & Take & & & \multirow{6}{*}{$\begin{array}{c}5-10 \% \\
\text { of } \\
\text { export } \\
\text { volume }\end{array}$} \\
\hline Brown rice & $\begin{array}{c}\text { farmers } \\
\text { above the } \\
\text { normal }\end{array}$ & 14.000 & & $\begin{array}{l}\text { profit } \pm \\
10 \% \text { of } \\
\text { the }\end{array}$ & $\begin{array}{c}\text { The range } \\
\text { of Rp. }\end{array}$ & $\begin{array}{l}\text { Consignment } \\
\text { / } 1 \text { month }\end{array}$ & \\
\hline Black Rice & $\begin{array}{l}\text { market } \\
\text { price and }\end{array}$ & 15.000 & & $\begin{array}{l}\text { consumer } \\
\text { price }\end{array}$ & 40.000 & deferred & \\
\hline White rice & middleme & 13.000 & & pris & \multirow{3}{*}{$\begin{array}{c}\text { The range } \\
\text { of Rp. } \\
22.000- \\
30.000\end{array}$} & \multirow{3}{*}{$\begin{array}{l}\text { Sell End / } \\
\text { Cash }\end{array}$} & \\
\hline Brown rice & $\begin{array}{l}\mathrm{n} \text { around } \\
\text { Rp. } \\
5.000-\end{array}$ & 14.000 & & 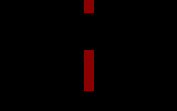 & & & \\
\hline Black Rice & 5.700 & 15.000 & & $\pi$ & & & \\
\hline
\end{tabular}

\section{Marketing Channel Analysis}

Based on observations on each organic food marketing channel in Jakarta, Bogor, Bandung, Cianjur, and Tasikmalaya, they all have the same goal of creating a sustainable market.
Some experts say that the direct selling system is a sustainable marketing channel for farmers/producers. However, farmers need to be supported by communities such as farmer groups 
(Gapoktan) to maintain competitiveness in the market.

On the other hand, although market demand for organic food certification is high, it is still challenging to be met by small farmers. The high price of certification and the lengthy certification process have made things difficult for small farmers. Based on the actors playing in the B-to-B market, some complained about the consignment payment system. The deferred payment system does not seem suitable for a perishable product. Marketing efficiency in the value chain of organic food can be seen from how significant the benefits are received by small farmers (farmers' share). The more intermediaries such as the middleman making organic food chains are getting longer, potentially giving fewer benefits to the farmers. An efficient marketing channel can be seen in the Bandung area, where small farmers, supported by the organic food community, sell their crops directly to the market without middlemen.

\section{Alternative Marketing Channel}

The challenges faced by traditional farmers are oversupply and limited market access - causing the bargaining power of organic products to be weak, as seen from the price of organic products, which are the same as non-organic products' prices. In modern farmers who access retail channels and partly in horeca, the suspension of payment can inhibit farmers in the production process. From these findings, alternative marketing channels that can be mapped are as follows (Figure 6).

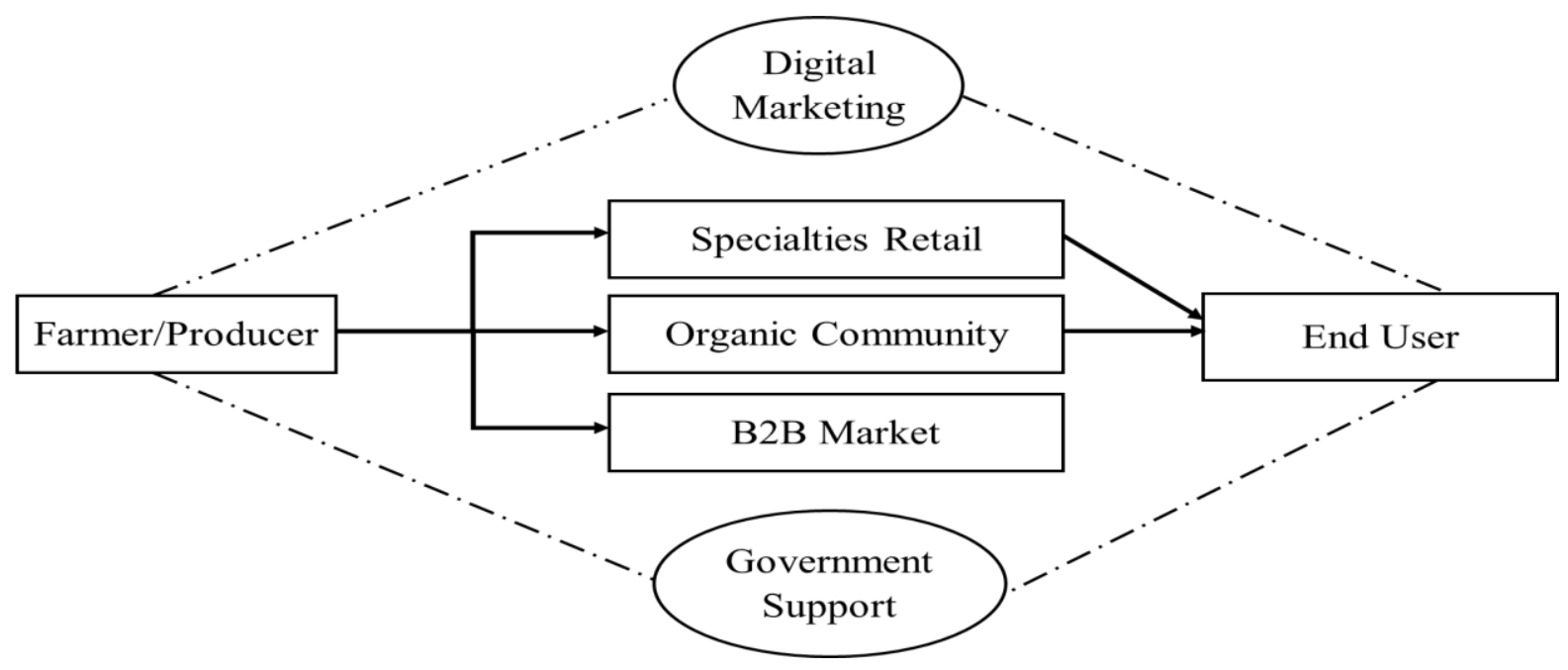

Figure 6. Alternative Organic Food Marketing Channel 
From the producers' perspective, organic products' potential marketing in terms of quantity, price, and no refund criteria are through direct marketing by utilizing digital marketing and organic communities. Based on the case of organic product marketing in Indonesia, the results support Nuutila \& Kurppa (2017) that collaboration both vertically and horizontally can provide a fairer price share for each actor in the distribution channel. In Indonesia, the most potential alternative markets to be considered are B2B market access, such as hospitality cooperation, restaurants, cafes, hospitals, and the healthy food processing industry. However, B2B access requires strong government support.

\section{CONCLUSION AND POLICY RECOMMENDATION}

Based on the study result, we can conclude that basically, the market opportunity for organic food is quite large, especially for female consumers aged between $20-50$ years and highly educated. Potential consumers of organic products in Indonesia are those who have an income above 9 million IDR. Differentiating products with certification labeling is an effective marketing strategy for credence goods such as organic food products. Even nowadays, upper-middle-class society also considers traceability of the products offered through the QR Code.

On the other hand, organic marketing channels in Indonesia are still very varied. The absence of government program in downstream organic products has become an obstacle for producers, especially for traditional farmers. Moreover, marketing management training has not yet become part of the "go organic" government program.

From the producers' perspective, organic products' potential marketing in terms of quantity, price, and no refund criteria are through direct marketing by utilizing digital marketing and organic communities. Both vertically and horizontally, collaboration can provide a fairer price share for each actor in the distribution channel. However, the B2B market needs government support in terms of accessing the horeca industry.

Difficulties in obtaining complete data on price changes in each marketing channel become a limitation in this study. Therefore, further research is expected to provide a marketing channel mapping in each region based on margin share distribution for each organic food chain actor in every product category. Likewise, the analysis of each marketing 
channel's efficiency and effectiveness is also very interesting for further study.

\section{ACKNOWLEDGMENT}

This research was financially supported by a research grant provided by the Ministry of Research, Technology, and Higher Education of the Republic of Indonesia. We would like to thank all those who have assisted us in the process of building this paper.

\section{REFERENCES}

Basha, M.B., Mason, C., Shamsudin, M.F., Hussain, H.I., \& Salem, A.M. (2015). Consumer attitude towards organic food. Procedia Economics and Finance (31) 444-452. doi:https://doi.org/10.1016/S22125671(15)01219-8

Drexler, D,, Fiala, J., Havlickova, A., \& Potuckova, A. (2017). The effect of organic food labels on consumer attention. Journal of Food Products Marketing. 24(1): 1-15. doi:10.1080/10454446.2017.131815

FiBL. (2019). The World of Organic Agriculture. In The World of Organic Agriculture Statistic and emerging trends 2019. https://doi.org/10.4324/97818497759 91

Global Organic Trade Guide. 2018. https://globalorganictrade.com/countr y/indonesia. Accessed online in 2018.

Groff, A.J., Kreidor, C.R., \& Toensmeyer, U.C. (1993). Analysis of the Delaware market for organically grown products. J. Food Distrib. Res., 24, 118-125.

Harris, B., Burress, D., \& Eicher, S. (2000). Demand for local and organic produce: A brief review of the literature (No. 254A). Institute for Public Policy and Business Research, University of Kansas, Lawrence, Kansas.
Hubeis, M., Najib, M., Widyastuti, H. \& Wijaya. N.H. (2013). Strategi produksi pangan organik bernilai tambah tinggi yang berbasis petani. Jurnal IImu Pertanian Indoensia. 18(3): 194-199.

Hughner, R.S., McDonagh, P., Prothero, A., Shultz, C.J. and Stanton, J. (2007). Who are organic food consumers? A compilation and review of why people purchase organic food. Journal of Consumer Behaviour 6(5), 94-110.

lqbal, M. (2015). Consumer behaviour of organic food: A developing country perspective. International Journal of Marketing and Business Communication. 4(4). doi:10.21863.ijmbc/2015.4.4024

Jassen, M., \& Hamm U. (2012). Product labelling in the market for organic food: Consumer preferences and willingness to pay for different organic certification logos. Food Quality and Preference. (25) 9-22. doi: 10.1016/j.foodqual.2011.12.004

Kaygisiz, F., Bolat, B.A. \& Bulut, D. (2019). Determining factors affecting consumer's decision to purchase organic chicken meat. Braz. J. Poult. Sci., 21

Kim, R., Suwunnamek, O., \& Toyoda, T. (2008) Consumer attitude towards organic labeling schemes in Japan. Journal of International Food \& Agribusiness Marketing, 20:3, 55-71, DOI: $10.1080 / 08974430802157622$

Larceneux, F., Moreau, F.B., \&Renaudin, V. (2012). Why might organic label fail to influence consumer choices? Marginal labelling and brand equity effects. Journal of Consumer Policy. 35(1): 85-104, doi:10.1007/s10603011-9186-2

Lemeshow, S., Hosmer, D.W., Klar, J \& Lwanga, S.K. 1997. Sample size in health research. Jogjakarta: Gajahmada University Press.

Magnusson, M.K., Arvola, A., Koivisto Hursti, U.K., Åberg, L., Sjödén, P.O. (2003). Choice of organic foods is 
related to perceived consequences for human health and to environmentally friendly behaviour. Appetite 40:109-117. doi:10.1016/ S0195-6663(03)00002-3

Muhammad, S., Fathelrahman, E., \& Ullah, R.U.T. (2016). The significant of consumer's awareness about organic food product in the United Arab Emirates. Sustainability, 8(833). doi: $10.3390 /$ su8090833

Muzayanah, F.N., Suroso, A.I., \& Najib, M. (2015). Faktor-faktor yang Memengaruhi Resistensi Pembelian Pangan Organik dan Proses Pendidikan Konsumen. Jurnal Manajemen \& Agribisnis, 12(3), 163173.

Nuutila, J., \& Kurppa, S. (2017). Two main challenges that prevent the development of an organic food chain at local and national level-an exploratory study in Finland. Organic Agriculture, 7, 379-394. https://doi.org/10.1007/s13165-0160163-5

Oroian, C.F., Safirescu, C.O., Harun, R., Chiciudean, G.O., Arion, F.H., Muresan, I.C., \& Bordeanu, B.M. (2017). Consumers' attitudes towards organic product and sustainable development: A case study of Romania. Sustainability (9) 1559. doi: 10.3390/su9091559

Pearson, D., Henryks, J., \& Jone, H. (2010). Organic food: what we know (and do not know) about consumers. Renewable Agric Food Syst., 26(2):171-177. doi:10.1017/S1742170510000499

Percsi, K.N., \& Fogarassy, C. (2019). Important influencing and decision factors in organic food purchasing in Hungary. Sustainability, 11(6075). doi:10.3390/su1121675

Radman, Marija. (2005). Consumer consumption and perception of organic products in Croatia. British Food Journal, 107(4), 263-273
Rodiger, M., Plabmann, S., \& Hamm U. (2016). Price knowledge, willingnessto-pay and purchase decision. British Food Journal. 118(11)

Rodríguez-Bermúdez, M., Miranda,I., Orjales, M.J., Ginzo-Vilamayor, W., Al-Soufi, M., López-Alonso. (2020). Consumers' perception of and attitudes towards organic food in Galicia (Northern Spain). Int. J. Consum. Stud., 44(3), 206-219.

Septiani, S., Najib, M., \& Sumarwan, U. (2019). Egoistic and altruistic motives on the purchasing behavioral model of organic food in the Indonesian market. Proceedings of the 2019 International Conference on Organizational Innovation.

https://doi.org/10.2991/icoi-19.2019.8

Sharma, N \& Singhvi, R. 2018. Consumers perception and Behaviour towards organic food: A systematic review of literature. Journal of Pharmacognosy and Phytochemistry. 7(2): 2152-2155.

Shepherd, R., Magnusson, M., \& Sjödén, P.O. (2005). Determinants of consumer behavior related to organic foods. Ambio, 34(4-5): 352-359. doi:10.1579/0044-7447-34.4.352

Soltani, S., Azadi, H., Mahmoudi, H., \& Witlox, F. (2014). Organic agriculture in Iran: Farmers' barriers to and factors influencing adoption. Renewable Agriculture and Food Systems, 29(2), 126-134.

Sotarra, A., \& Bentler, P.M. (2010). Ensuring Positiveness of the Scaled Difference Chi-square Test Statistic. Psychometrika, 75, 243-248.

Sultan, P., Wong, H.Y., \& Sigala M. (2018). Segmentating the Australian organic food consumer market. Asia Pasific Journal of Marketing and Logistics, 13(1), 163-281, doi: 10.1108/APJML10-2016-0211.

Torres-Ruiz, F.J. \& Vega-Zamora, M. (2018). Parras-Rosa, M. Sustainable consumption: Proposal of a multistage model to analyse 
consumer behaviour for organic foods. Bus. Strateg. Environ., 27, 588-602.

Vega-Zamora, M., Parras-Rosa, \& TorresRuiz, F.J. (2020). You are what you eat: The relationship between values and organic Food consumption. Sustainability, 12, 3900.

Wang, X.H., Pacho, F., Liu, J., \& Kajungiro, R. (2019). Factors influencing organic food purchase intention in developing countries and the moderating role of knowledge. Sustainability, 11, 209.

Yee, C.J., San, N.C., \& Khoon, C.H. (2011). Customers' perceived quality, perceived value, and perceived risk towards purchase decision on automobile. American Journal of Economics and Business Administration, 3, 47-57 
